\title{
The concept of gene in the twenty-first century: What are the open avenues?
}

\section{El concepto de gen en el siglo veintiuno. ¿Qué vías están abiertas?}

\author{
CHARBEL NIÑO EL-HANI \\ History, Philosophy and Biology Teaching Lab (LEHFBio), Institute of Biology, \\ Federal University of Bahia, Salvador, (Brazil). \\ DIOGO MEYER \\ Institute of Biosciences, University of São Paulo, São Paulo, (Brazil)
}

\begin{abstract}
The view of the gene as a structural and functional unit has been increasingly challenged by findings mostly resulting from eukaryote research. We can classify these challenges in three kinds: (i) one-to-many correspondences between DNA segments and RNAs/polypeptides (as, for instance, in alternative splicing); (ii) many-to-one correspondences between DNA segments and RNAs/polypeptides (as in genomic rearrangements, say, those involved in the generation of diversity in lymphocyte antigen receptors); (iii) lack of correspondence between DNA segments and RNAs/polypeptides (as, for example, in mRNA editing). However, even if a single definition of a gene may not be a realistic (or even helpful) goal, being able to have different definitions connected to each other-operationally and theoretically- is of central importance.
\end{abstract}

KEYWORDS

GENE CONCEPT, DEFINITION, DNA

\section{RESUMEN}

La idea según la cual el gen es una unidad estructural y funcional se ha visto cada vez más cuestionada a causa de descubrimientos realizados en investigaciones con eucariotas. Podemos 
clasificar los desafíos planteados a dicha idea en tres tipos: (i) correspondencias uno-a-muchos entre segmentos de ADN y ARN/polipéptidos (como, por ejemplo, en el empalme alternativo); (ii) correspondencias muchos-a-uno entre segmentos de ADN y ARN/polipéptidos (como en las reorganizaciones genómicas, tales como las implicadas en la generación de diversidad en los receptores de antígenos de los linfocitos); (iii) falta de correspondencia entre segmentos del ADN y ARN/polipéptidos (como, por ejemplo, en la edición del ARNm). Sin embargo, incluso si, por estas razones, no sería realista (o incluso útil) buscar una definición única de gen, es de capital importancia que seamos capaces de formular diferentes definiciones conectadas entre sí teórica y operacionalmente.

\author{
PALABRAS CLAVE \\ CONCEPTO DE GEN, DEFINICIÓN, ADN
}

\title{
I. INTRODUCTION: THE CRISIS OF THE GENE CONCEPT
}

THE GENE CONCEPT HAS BEEN ONE OF THE LANDMARKS in the history of science in the $20^{\text {th }}$ century. However, there are nowadays persistent doubts about the meaning and contributions of this concept. There are negative and positive reactions to the problem of the gene (El-Hani 2007). For instance, while Keller (2000) suggested that we should leave the gene concept aside, Knight (2007) claimed that «reports of the death of the gene are greatly exaggerated». The crisis of the gene concept is related to its persistent interpretation as a stretch of DNA that encodes a functional product, a single polypeptide chain or RNA molecule, i.e., the so-called classical molecular gene concept (Griffiths \& Neumann-Held 1999; Neumann-Held 1999; Stotz et al. 2004).

This concept brought together structural and functional definitions of the gene, alongside with an easily understandable mechanics, and showed considerable heuristic power in genetics and molecular biology. However, this picture changed since the 1970s, as the view of the gene as a structural and functional unit was increasingly challenged by findings mostly resulting from eukaryote research. We can classify these challenges in three kinds: (i) oneto-many correspondences between DNA segments and RNAs/polypeptides (as, for instance, in alternative splicing, Black 2003; Graveley 2001); (ii) many-toone correspondences between DNA segments and RNAs/polypeptides (as in genomic rearrangements, say, those involved in the generation of diversity in lymphocyte antigen receptors, Cooper \& Alder 2006; Murre 2007); (iii) lack of correspondence between DNA segments and RNAs/polypeptides (as, for example, in mRNA editing, Hanson 1996; Lev-Maor et al. 2007). 


\section{REFORMULATING THE GENE CONCEPT}

Several proposals for reformulating the gene concept appeared in the last 20 years. We will just mention some of them here, with no intention of being exhaustive or providing detailed discussion. ${ }^{1}$ Some authors argued against the idea of genes as units and proposed, instead, views about genes as combinations of nucleic acid sequences that correspond to a given product (Fogle 1990,2000; Pardini \& Guimarães 1992) and might be located in processed RNA molecules (Scherrer \& Jost 2007a,b). These proposals accommodate challenges such as overlapping and nested genes by denying the idea of genes as units in DNA.

Fogle $(1990,2000)$, for instance, treats genes as sets of domains in DNA, an assemblage of embedded, tandem, and overlapping domains, «[...] a collection of component entities that together define its structure and influence the phenotype» (Fogle 1990, p. 367). Domains are nucleotide sequences that can be distinguished from each other on the basis of their structural properties and/or activities: exons, introns, promoters, enhancers, operators, leader and trailer sequences, etc. In this manner, genes are not in DNA anymore, but only domains, what allows this proposal to accommodate many challenges to the classical molecular concept.

Other authors put forward a process-oriented view of genes. In NeumannHeld's «process molecular gene concept», for instance, genes are not treated as «bare DNA», but as the whole molecular process «[...] that leads to the temporally and spatially regulated expression of a particular polypeptide product» (Griffiths \& Neumann-Held 1999, p. 659). Since different epigenetic conditions that affect gene expression are in this way built into the gene, this proposal can accommodate challenges such as alternative splicing or mRNA editing. Epp (1997) proposed that we need to separate two distinct concepts related to genes, namely, a specification of what is a gene and an indication of how it is used. He claims that the term «gene» points to the former, but Griffiths and Neumann-Held take the contrary position, arguing that it points to the latter. They justify this option by emphasizing that «the concept of the gene has always been intimately linked to how genes are used in development» (Griffiths and Neumann-Held 1999, p. 658). In the process molecular gene, the focus lies on gene function. A description of what a gene is as a physical entity is taken as a necessary but not sufficient condition to understand it, given the contextdependence of gene function.

Moss $(2001,2003)$ distinguished between two meanings ascribed to genes and, consequently, demarcated two concepts, gene-P and gene-D, which have been usually conflated throughout the $20^{\text {th }}$ century. ${ }^{2}$ Gene-P amounts to the gene

1 For detailed discussion, see Meyer et al. (in press).

2 Knight (2007) provides critical comments on Moss' proposal to distinguish between 
as determinant of phenotypes or phenotypic differences. It is an instrumental concept, not accompanied by any hypothesis of correspondence to reality, and this is what allows one to accept the simplifying assumption of preformationist determinism. A simple genotype-phenotype mapping is accepted for the sake of modeling. Indeed, Gene-P is useful to perform a number of relevant tasks in genetics, such as pedigree analysis. When we refer to gene-P, we speak of it as if it caused, by itself, a phenotype, as in the commonly used concept of a «gene for» (Kendler 2005), which became rather central in «gene talk» (Keller 2000) in science and society. For instance, when we speak of the gene for blue eyes, we speak of the genes as if they determined the trait «blue eyes». However, there are many cases in which the «gene for» the trait has no material counterpart, for example, when several alleles affect the normal functioning of the biochemical processes involved in the development of the trait -say, the biochemical pathways that lead to the synthesis of eye pigments. The concept «gene for blue eyes» corresponds, in fact, to a disjunction of alleles that can be responsible for a decrease of pigmentation in the iris. And, certainly, this disjunction is a logical expression, not a material entity to which the concept can be said to refer. This does not deny, however, the usefulness of the concept: to understand the results of a crossing between a brown-eyed father and a blue-eyed mother, we can readily use pedigree analysis, accompanied by the apt simplification of assuming that there are genes that determine the presence of brown or blue eyes. We can say, thus, that gene-P is an instrumental concept that has predictive power and plays an important role in some explanatory games of genetics and molecular biology. It is capable of doing so through the assumption of simple genotype-phenotype mapping, which is not problematic when restricted to this context. But this did not happen in the history of genetics.

Gene-D, in turn, amounts to the gene as a developmental resource in causal parity (Griffiths \& Knight 1998) with other such resources (say, epigenetic ones). It is conceived as a real entity defined by some molecular sequence in DNA which acts as a transcription unit and provides molecular templates for the synthesis of gene products. It is in itself indeterminate with respect to the phenotype (Moss 2003, p. 46), that is, a gene-D typically does not determine by itself phenotypic traits, but acts as a developmental resource involved in the construction of traits, alongside with other equally important resources, such as epigenetic and environmental factors.

Model reification is a recurrent problem in science and simplifying assumptions used for the sake of modeling often become loaded with metaphysical connotations. Thus, simple genotype-phenotype mapping was projected onto

gene-P and gene-D. We will not deal with these comments here, but they were addressed in Meyer et al. (in press). 
The concept of gene in the twenty-first century...

reality, giving rise to genetic determinism, a view with serious socioscientific consequences (for a recent discussion, see Scott 2013). As a consequence of such reification, gene-P and gene-D has been and still are conflated. But, as Moss argues, even though genes can be productively conceived in these two different ways, nothing good results from their conflation (Moss 2001, p. 85).

The ENCyclopedia of DNA Elements (ENCODE) project is an international scientific consortium aiming at identifying the functional elements in the human genome sequence. ${ }^{3}$ Among its contributions, we find a new definition of gene: «[...] a union of genomic sequences encoding a coherent set of potentially overlapping functional products» (Gerstein et al. 2007, p. 677, emphasis in the original). Here, different functional products of the same class (proteins or RNAs) that overlap in their usage of the same primary DNA sequences are combined in the same gene, and, thus, several challenges to the classical molecular concept are accommodated by abandoning the unitary relationship between genes, gene products, and gene function. For instance, the products of alternative splicing are taken to be products of a single gene, since they share sequences in common. Scherrer and Jost (2007b) criticize the ENCODE definition of the gene for neglecting regulation, a fundamental aspect of genomic systems, since it mediates between codification and function, the aspects highlighted by that definition.

Some works strive for solving the gene problem by building new languages that cut up the genetic system into novel categories, organizing our understanding into different sets of concepts (Keller \& Harel 2007; Scherrer \& Jost 2007a,b). On the one hand, this may solve, or dissolve, problems and limits posed by our current language about genes. On the other, there is an expected difficulty of translation between the new languages and the ones already established in the fields of genetics and molecular biology, which may hamper researchers' understanding of those new ways of speaking and, thus, their acceptance. To maintain sufficient bridges between new and older ways of speaking seems crucial for the success of these proposals.

Keller and Harel (2007) propose an alternative to both the concept and the word «gene», replacing them by a closely related concept and term, although situated in an entirely different logical level, the dene. The dene is part of a more encompassing concept, the genetic functor, ${ }^{4}$ or genitor, $\mathrm{G}$, defined as a triple $G=(O, D, B)$, where $O$ is an organism of a specified type (i. e., with spe-

3 The ENCODE database can be reached at http://www.genome.gov/10005107\#4. The participants of the ENCODE can be found at http://www.genome.gov/26525220. See also The ENCODE Project Consortium (2004).

4 In category theory, a functor is a special type of mapping between categories, informally defined as maps between categories that preserve structures or, alternatively, as a homomorphism between categories (Marquis 2011). 
cified genetic and behavioral properties), $D$, a dene, and $B$, a bene. The dene is a statement about $O$ 's DNA (or, more precisely, a truth-valued function of $O$ 's DNA sequence) and the bene, a statement about $O$ 's behavior (more precisely, a truth-valued function of $O$ 's temporal life-span).

The dene is a concept intending to capture the bases of genetic transmission, but, differently from the gene, it does not denote merely a stretch of DNA. Rather, a dene is a general kind of statement about DNA (a predicate or property) representing much more intricate characteristics of this molecule than the simple statement that it contains a particular expressed subsequence. Even though the constitutive elements of the dene are in DNA, the dene itself does not reside in this molecule, because it is at a different logical level, as a statement about it, or designated property of it. The dene may refer to the entire genome of an organism, or to some contiguous or disjoint parts of it, with fixed or variable boundaries, and with overlapping or iterated subsequences, possessing functional meaning, even if not expressed. The dene is, thus, a very flexible statement about DNA, which can accommodate challenges to the classical molecular concept.

Keller and Harel's framework has a distinctive advantage in relation to our current language about genes: it provides a clearer separation between structure, that is, what constitutes the organism and, thus, what it materially inherited, and function, that is, what the organism dynamically does with what it inherited, or, to put it differently, its functionality and behavior. The dene is a statement about DNA as a static entity and, thus, says nothing about function in and by itself. It is the bene that specifies the behaviors associated to (not determined by) DNA sequences, as a statement about how the organism dynamically develops, lives, behaves, etc. This is a broad and rich statement, referring to complex modal and temporal characteristics of the organism's behavior over time, irreducible to simple statements about, say, protein synthesis or transcription.

Finally, it is the genitor that expresses the functional relation between $D$ and $B$, connecting static and dynamic aspects. This relation is more complex than the simple genotype-phenotype mapping found in genetic determinism: the bene does not simply follow from the dene, but only has the dene as one of its parts, alongside with $O$ 's environment, developmental mechanisms, epigenetic processes, and so on.

In their proposal of a new language to talk about genetic systems, Scherrer and Jost $(2007 \mathrm{a}, \mathrm{b})$ depart from two distinct aspects involved in the production of polypeptides -coding and regulation- to arrive at the proposal that we need distinct terms to account for them. The problem of the gene is conceived, thus, as resulting from the ascription of a very large diversity of meanings to a single term. Conceptual analysis can help, then, in solving this problem, as it leads to new concepts and terms that embrace meanings previously captured by «gene». For Scherrer and Jost, our understanding of gene expression should be broken 
up into gene function, on the one hand, and the mechanisms of storage and expression, on the other. The gene is mostly related to the functional aspect. We cannot found at the DNA level, however, a unit that can account for gene function. They propose, then, that the gene emerges at the level of mature RNAs, a claim that we will discuss in the next section.

The second aspect, regulation, is related to the process of creation of the gene in RNA out of pieces in the genome, which Scherrer and Jost call «genomic domains». ${ }^{5}$ They stress the role of a programme that comes along with the transcript and «[...] secures the generation of the gene, in the cellular space and in time, through the many steps of gene expression» (Scherrer \& Jost 2007a, p. 3). ${ }^{6}$ This cis-acting regulatory programme is, in their vocabulary, the «genon» (a contraction of the terms «gene» and «operon»), which amounts to the additional information needed to gene expression, contained within each RNA as an ensemble of signals, that is, potential binding sites for regulatory proteins, RNAs or ribonucleoproteins. The genon is both added to and superimposed onto the coding sequence. Each genon is unique to each distinct mRNA and polypeptide and, thus, to each gene, even though two different genes and genons can share DNA segments. When the cell builds a gene out of DNA sequences, it also builds a corresponding genon.

Besides the cis-acting regulatory programme corresponding to the genon, gene regulation depends on an ensemble of regulatory factors codified in other chromosomes that potentially recognize and act on the signals in cis found in a given genon. Scherrer and Jost call this ensemble the «transgenon». As the genon of an mRNA is immersed into a pool of trans-acting factors («holotransgenon») which are capable of recognizing signals or «oligomotifs» in the nucleotide sequence, a specific transgenon is selected out by each genon. It is from this genon-transgenon specific interaction that the regulation of gene expression emerges.

5 A «genomic domains» is defined by Scherrer and Jost (2007b, p. 106) as a «DNA domain containing fragments of one or several genes coordinated by cis controls separated, possibly, by insulators, often unit of transcription and, in some cases, of replication». This concept is potentially important for dealing with the problem of intergenerational transmission if genes are located in RNA, as we will discuss below.

6 The notion of «program», particularly when conceived in terms of «genetic programs», is highly controversial (e.g., Oyama [1985]2000; Nijhout 1990; Griffiths \& Neumann-Held 1999, Keller 2000), but we will not pursue this discussion here, since it would take us away from our major goals in this paper. Scherrer and Jost do not elaborate on the concept of «programme», although they say that the genon and transgenon constitute a flexible, not rigidly defined program, to the extent that epigenetic mechanisms of gene expression and transmission modify both the genon and its precursors at the DNA level. 
After translation of a gene found at the mature RNA level ends up, the gene is degraded alongside with the genon. As genes are conceived in this framework as being created by the cell from their parts encoded in genomic domains in DNA and then degraded, they become much more dynamic entities than they are in the current picture. Not only challenges to the classical molecular concept are overcome by this proposal (with some remaining exceptions, such as alternative modes of translation), but a distinctly different way of understanding genes comes to the fore. But is it really reasonable to locate genes in RNA?

\section{GENES IN RNA?}

As we mentioned above, Scherrer and Jost (2007a,b) locate the gene at the level of mature RNAs. They propose the following definition for «gene»:

[...] the uninterrupted nucleic acid stretch of the coding sequence in the mRNA that corresponds to a polypeptide or another functional product; thus, in eukaryotes typically not yet present at DNA level, but assembled from gene fragments (exons) in course of RNA processing (Scherrer \& Jost 2007b, p. 106).

For Scherrer and Jost, this uninterrupted mRNA sequence is the unit of function and genetic analysis, as the equivalent of the polypeptide chain when reliably translated. They build this argument by focusing mostly on proteincoding genes. In the case of genes transcribed into RNA molecules that are not translated, the situation is a bit more complex. After all, if there is no processing involved in the synthesis of a functional RNA, we might locate the gene at the DNA level. However, we need to consider how often functional RNAs are processed and, thus, could have genes located only at the RNA level. In fact, most kinds of functional RNAs experience post-transcriptional editing. For example, tRNA (e.g., Abelson et al. 1998), rRNAs (e.g., Cech et al. 1981), siRNAs, miRNAs (e.g., Pontes \& Pikaard 2008), and snoRNAs (e.g., Giorgi et al.2001) all have been documented to experience either splicing or editing events subsequent to the generation of the primary transcript. For the sake of coherence and generality, it is better to locate also in these cases the gene at the functional RNA level, claiming that, in the exceptional cases where no processing is involved, what we would see is equivalence between genomic domain (in DNA) and gene (in RNA). It is curious, however, that the aspect of coding has no place in genes coding for RNA that are not translated, when conceived in these terms: the synthesis of functional RNAs does not depend on any set of rules to translate from one kind of polymer to another. But notice, first, that genes are more essentially related by Scherrer and Jost to a functional rather than a coding aspect, suggesting that we can identify genes with no coding involved. 
Second, that the problem that there is no coding involved in genes transcribed into functional RNA molecules is already present in the current framework of molecular biology. The only difference is that this problem comes to the fore when one intends to locate genes in RNA.

What could be the advantages of locating genes in RNA? First, it preserves the gene concept, which is not very likely to be dismissed (Judson 2001). Second, locating genes in RNA can dissolve several challenges that result from looking for a structural unit corresponding to the gene at the DNA level. Third, this proposal captures the idea of a translation unit and, also, of a transcription unit corresponding to the nucleotide sequences of several classes of functional RNAs. Fourth, there is a good relationship between the location of genes in RNA and operational procedures carried out by molecular biologists and geneticists, such as those for counting genes.

However, there are also problems with this proposal. First, a close relationship between genes and DNA has marked biological discourse since the double helix (Joaquim \& El-Hani 2010). To separate genes from DNA is, in fact, a substantial effort of reconceptualization, but this may be the price to pay in order to rebuild a consistent, parsimonious, and explanatorily powerful account of genes. Second, it is difficult to think that genes would only exist in the zygote as mere possibilities (Keller 2000), since the gene would only be in RNA, and in metazoans most of the transmission of genetic information takes place through DNA. Third, if located in RNA, genes would not have the permanence and stability usually attributed to them, as a requirement for inheritance. Regarding the latter problems, we can replace genes by other intergenerationally stable entities when explaining inheritance. Genomic domains (as proposed by Fogle 1990, and Scherrer and Jost 2007a,b), out of which genes are constructed by the cell, can play the role of mediating inheritance in the place of genes. Then, we might eliminate from the gene the ideas of permanence and stability, making it more reasonable to conceive it as a unit of structure and genetic analysis in mature RNAs. ${ }^{7}$ Evidently this cannot settle the discussion. It is far from being simple and straightforward to disentangle the aspects of permanence and stability from the gene: these aspects and, more generally speaking, the role of genes in inheritance are at the heart of the gene concept since the very beginnings of genetics!

7 Scherrer and Jost $(2007 \mathrm{a}, \mathrm{b})$ treat the gene as both a structural and a functional unit at the RNA level. We do not consider, however, that a functional unit can be located in a nucleic acid, no matter if DNA or RNA, due to the context-dependence of gene function, which demands that we conceive of function in terms of causal roles played by higher-level entities and processes in a cell. Both DNA and RNA are evidently related to the emergence of these causal roles, but not as units to which these causal roles could be reduced. Nevertheless, we cannot expand this discussion here. 


\section{CONCLUDING REMARKS}

All these proposals for overcoming the problem of the gene share a shortcoming: they keep the intention of proposing a single and all-encompassing definition for gene. Genes are, however, epistemic objects constructed and used in several biological subdisciplines for a diversity of (explanatory, predictive, heuristic) tasks. From this diversity of tasks, a diversity of meanings ascribed to genes as epistemic objects (Rheinberger 2000) naturally follows. The right expectation, thus, should not be one of proposing a single definition for «gene», but, rather, one of providing a clear demarcation of different meanings ascribed to this central concept in genetics and molecular biology.

It is particularly informative to consider the differing usages of the «gene» that are found in important subdisciplines of biology. Consider the field of population genetics, which is concerned with how allele frequencies change over time. In this subdiscipline, the vast majority of theoretical work carried out treats genes as entities that can modeled from a Mendelian perspective. In other words, genes are treated as «balls» which are randomly sampled in the process of meioses and placed in «urns» (the new population formed by the transmission of gametes). To many of the questions of population genetics, the molecular structure, physiological consequences or functional attributes of this entity is irrelevant to the modeling process, which is focused on developing models that make general predictions on the relative abundance of variant forms of these «balls» in each generation.

Such a perspective lies in strong contrast to a view of the gene as a structural unit, where its attributes, extension, precise phenotypic effects, among other attributes, are of central importance to questions being addressed. In this context, knowing the bounds and functional attributes of the gene will be very directly linked to the success in addressing the scientific questions that motivate ongoing research.

However, in closing, it is appropriate to keep in mind inherent limitations associated to the adherence to gene concepts that are meaningful in the context of a particular subdiscipline. This limitation naturally emerges as that subdiscipline itself encounters limitations in carrying out its research program. For example, if we are adopting a «balls in urns» model of a gene in order to understand the evolutionary dynamics of a species, it may be of key importance to understand how that gene is expressed, and how its expression modulates the phenotype, thus influencing how its change in frequency over generations will take place. An appropriate definition of what constitutes the «ball» in this case may include 
having a proper grounding in functional information, allowing the prediction of the phenotypic effects to be considered.

The above reasoning illustrates how even if a single definition of a gene may not be a realistic (or even helpful) goal, being able to have different definitions connected to each other -operationally and theoretically- is of central importance.

\section{REFERENCES}

ABELSON, J., TROTTA C. R. \& LI, H. (1998). «tRNA splicing». The Journal of Biological Chemistry, 273, 12685-12688.

BLACK, D. L. (2003). «Mechanisms of alternative pre-messenger RNA splicing». Annual Review of Biochemistry, 72, 291-336.

CECH, T. R., ZAUG, A. J. \& GRABOWSKI, P. J. (1981). «In vitro splicing of the ribosomal RNA precursor of Tetrahymena: Involvement of a guanosine nucleotide in the excision of the intervening sequence». Cell, 27, 487-496.

COOPER, M. D. \& ALDER, M. N. (2006). «The evolution of adaptive immune systems». Cell, 124, 815-822.

EL-HANI, C. N. (2007). «Between the cross and the sword: The crisis of the gene concept». Genetics and Molecular Biology, 30, 297-307.

EPP, C. D. (1997). «Definition of a gene». Nature, 389, 537.

FOGLE, T. (1990). «Are genes units of inheritance?» Biology and Philosophy, 5, $349-371$.

FOGLE, T. (2000). «The dissolution of protein coding genes». In: P. Beurton, R. Falk \& H-J. Rheinberger (Eds.), The concept of the gene in development and evolution (pp. 3-25). Cambridge: Cambridge University Press.

GERSTEIN, M. B., BRUCE, C., ROZOWSKY, J. S., ZHENG, D., DU, J., KORBEL, J. O., EMANUELSSON, O., ZHANG, Z. D., WEISSMAN, S. \& SNYDER, M. (2007). «What is a gene, post-ENCODE? History and updated definition». Genome Research, 17, 669-681.

GIORGI, C., FATICA, A., NAGEL, R. \& BOZZONI, I. (2001). «Release of U18 snoRNA from its host intron requires interaction of Noplp with the Rntlp endonuclease». The EMBO Journal, 20, 6856-6865.

GRAVELEY, B.R. (2001). «Alternative splicing: Increasing diversity in the proteomic world». Trends in Genetics, 17, 100-107.

GRIFFITHS, P.E. \& KNIGHT, R.D. (1998). «What is the developmental challenge? » Philosophy of Science, 65, 2, 253-258.

GRIFFITHS, P. E. \& NEUMANN-HELD, E. (1999). «The many faces of the gene». BioScience, 49, 656-662.

HANSON, M. R. (1996). «Protein products of incompletely edited transcripts are detected in plant mitochondria». The Plant Cell, 8(1), 1-3. 
JOAQUIM, L. M., \& EL-HANI, C. N. (2010) «A genética em transformação: Crise e revisão do conceito de gene». Scientiae Studia, 8, 93-128.

JUDSON, H. F. (2001). «Talking about the genome». Nature, 409, 769.

KELLER, E. F. (2000). The century of the gene. Cambridge, MA: Harvard University Press.

KELLER, E. F. \& HAREL, D. (2007). Beyond the gene. PLoS One, 2, e1231.

KENDLER, K. S. (2005). «'A gene for...': The nature of gene action in psychiatric disorders». American Journal of Psychiatry, 162, 1243-1252.

KNIGHT, R. (2007). «Reports of the death of the gene are greatly exaggerated». Biology and Philosophy, 22, 293-306.

LEV-MAOR, G., SOREK, R., LEVANON, E. Y., PAZ, N., EISENBERG, E. \& AST, G. (2007). «RNA-editing-mediated exon evolution». Genome Biology, 8, R29.

MARQUIS, J.-P. (2011). «Category theory». In: E. N. Zalta (Ed.). The Stanford Encyclopedia of Philosophy (Spring 2011 Edition).

$<$ http://plato.stanford.edu/archives/spr2011/entries/category-theory/>. Retrieved August $6^{\text {th }} 2012$.

MEYER, L. M. N., BOMFIM, G. C. \& EL-HANI, C. N. (in press). «How to understand the gene in the 21st century». Science \& Education. Available at: http://link. springer.com/article/10.1007/s11191-011-9390-z. Retrieved January $22^{\text {th }} 2013$.

MOSS, L. (2001). «Deconstructing the gene and reconstructing molecular developmental systems». In: S. Oyama, P. E. Griffiths \& R. D. Gray (Eds.), Cycles of contingency: Developmental systems and evolution (pp. 85-97). Cambridge, MA: MIT Press.

MOSS, L. (2003). What genes can't do. Cambridge, MA: The MIT Press.

MURRE, C. (2007). «Epigenetics of antigen-receptor gene assembly». Current Opinion in Genetics \& Development, 17, 415-421.

NEUMANN-HELD, E. (1999). «The Gene is dead - Long live the gene: Conceptualizing genes the constructionist way». In: P. Koslowski (Ed.). Sociobiology and bioeconomics: The theory of evolution in biological and economic thinking (pp. 105-137). Berlin: Springer.

NIJHOUT, H. F. (1990). «Metaphors and the role of genes in development». BioEssays, $12,441-446$

OYAMA, S. ([1985]2000). The Ontogeny of information: Developmental systems and evolution ( $2^{\text {nd }}$ ed.). Cambridge: Cambridge University Press.

PARDINI, M. I. M. C. \& GUIMARÃES, R. C. (1992). «A systemic concept of the gene». Genetics and Molecular Biology, 15, 713-721.

PONTES, O. \& PIKAARD, C. S. (2008). «siRNA and miRNA processing: New functions for Cajal bodies». Current Opinion in Genetics \& Development, 18 , 197-203.

RHEINBERGER, H.-J. (2000). «Gene concepts: Fragments from the perspective of molecular biology». In: P. Beurton, R. Falk \& H.-J. Rheinberger (Eds.), The concept of the gene in development and evolution (pp. 219-239). Cambridge: Cambridge University Press.

SCHERRER, K. \& JOST, J. (2007a). «The gene and the genon concept: A functional and information-theoretic analysis». Molecular System Biology, 3, 1-11. 
SCHERRER, K. \& JOST, J. (2007b). «The gene and the genon concept: Coding versus regulation. A conceptual and information-theoretic analysis of genetic storage and expression in the light of modern molecular biology». Theory in Biosciences, $126,65-113$.

SCOTT,E. C. (2013). «This I believe: we need to understand evolution, adaptation, and phenotype». Frontiers in Genetics, 3, 1-2.

STOTZ, K., GRIFFITHS, P. E. \& KNIGHT, R. (2004). «How biologists conceptualize genes: An empirical study». Studies in the History and Philosophy of Biological \& Biomedical Sciences, 35, 647-673.

The ENCODE Project Consortium (2007). «The ENCODE (ENCyclopedia Of DNA Elements) Project». Science, 306, 636-640.

Charbel El-Hant is Profesor Asociado at the Institute of Biology, Federal University of Bahia, Salvador (Brazil).

Research interests:

Philosophy of biology, biology teaching, history of biology, evolutionary biology and animal behavior

Recent publications:

SANTOS, V.C.; JOAQUIM, L. M. \& EL-HANI, C. N. (2012). «Hybrid deterministicviews about genes in biology textbooks: A key problem in genetics teaching». Science \& Education 21: 543-578. DOI: $10.1007 / \mathrm{s} 11191-011-9348-1$

ARTEAGA, J. M. S. \& EL-HANI, C. N. (2012). «Othering Processes and STS Curricula: From 19th Century Scientific Discourse on Interracial Competition and Racial Extinction to Othering in Biomedical Technosciences». Science \& Education 21: 607-629. DOI: 10.1007/ s11191-011-9384-x

Email: charbel@ufba.br

Diogo Meyer is professor at the Institute of Biosciences of the University of São Paulo (Brazil).

Research interests:

Evolutionary Biology and Population Genetics

\section{Recent publications:}

MEYER, D. and HARRIS, E. E, 2013. «Nonadaptive Genetic Change in Human and Primate Evolution», in Encyclopedia of Life Sciences, John Wiley \& Sons Ltd, Chichester. http:// www.els.net.

SEPÚlVEDA, C., MEYER, D., EL-HANI, CN. 2011. «Adaptacionismo». In: Paulo C. Abrantes. (Org.). Filosofia da Biologia. 1ed.Porto Alegre-RS: ARTMED. p. 162-192. 